\title{
STRATEGI PEMBANGUNAN KUALITAS MANUSIA: Suatu Perspektif Administrasi Publik
}

\author{
Tunggul Prasodjo \\ Dosen STISIP 17-8-1945 Makassar \\ e-mail: tunggul.prasodjo@gmail.com
}

\begin{abstract}
ABSTRAK
Tulisan ini bertujuan menjelaskan strategi pembangunan kualitas manusia dari perspektif administrasi publik. Metode yang digunakan adalah metode deskriptif, yaitu menggambarkan strategi pembangunan kualitas manusia dari berbagai literatur yang terkait dengan pembangunan sumberdaya manusia (SDM). Hasil kajian literatur menunjukkan bahwa pembangunan kualitas manusia birokrasi merupakan suatu keharusan untuk dapat memberikan pelayanan publik yang memuaskan. Strategi yang perlu dilakukan oleh pengelola SDM adalah dengan meningkatkan kualitas fisik dan psikis.
\end{abstract}

Kata kunci: Strategi Pembangunan, Sumberdaya Manusia.

\section{PENDAHULUAN}

Dari praktisi dan teoritisi sering didengar bahwa administrasi publik di negara berkembang memiliki berbagai kelemahan birokrasi tradisional, misalnya inefiensi, produktivitas rendah, kurang mampu melaksanakan tugas pembangunan, korup, dan sebagainya. Karena itu para ahli seperti Abdullah (1985), Bryant \& White (1987), Brett (1988), Evers (1988), Mustopadidjaya (1988), Tjokrowinoto (1989), Effendi (1990), Wibawa (2005), Wrihatnoto \& Nugroho (2006), dan Dwiyanto (2006) mensinyalir bahwa salah satu hambatan terbesar dalam pembangunan di negara berkembang, termasuk Indonesia, adalah sistem administrasi publik yang belum memiliki sumberdaya manusia yang cukup untuk melaksanakan berbagai kegiatan pembangunan yang semakin nyata.

$$
\text { Peranan pemerintah dalam }
$$
pembangunan tetap besar meskipun akan berubah bentuknya. Orientasi baru pembangunan memerlukan perubahan fungsi pemerintah dari "pelaku utama" menjadi "fasilitator". Untuk itu diperlukan suatu sistem administrasi publik yang berbeda dengan sistem yang kita anut selama ini. Sistem administrasi baru ini memerlukan struktur yang lebih "organis adaptif", simplifikasi prosedur memiliki orientasi produktivitas dan pelayanan publik, serta lingkungan politik-birokratik yang mampu memberikan pengawasan yang efektif (Brett, 1988; Effendi,1990).

\section{Konsep Strategi Pembangunan Sumberdaya Manusia}

Untuk menyamakan persepsi dan interpretasi tentang variabel yang dibahas, maka perlu dikutip beberapa definisi dari para pakar. Pada dasarnya strategi berasal dari bahasa Yunani yakni strategous "a general" (sesuatu yang bersifat 
menyeluruh). Dari pengertian ini dapat dikatakan bahwa strategi merupakan proses penentuan rencana pemimpin yang fokus pada jangka panjang. Oleh karena itu pemimpin birokrasi dapat memformulasikan strategi kerangka kerja peningkatan kemampuan SDM dalam jangka panjang, untuk mengantisipasi dan mendeteksi situasi ketidakpastian atau perubahan lingkungan di masa depan.

Bryson (1988:163) menyatakan bahwa strategi merupakan suatu pola tujuan, kebijakan, program, tindakan, keputusan, atau lokasi sumberdaya yang menunjukkan jati diri suatu birokrasi, halhal yang dilakukan beserta alasan melakukan hal-hal tersebut. Sedangkan yang dimaksud "pembangunan" menurut para pakar pembangunan, antara lain Theresia (2015:2), mengatakan bahwa pembangunan adalah suatu usaha atau proses perubahan demi tercapainya tingkat kesejahteraan atau kualitas hidup suatu masyarakat (dan individu-individu di dalamnya) yang berkehendak melaksanakan pembangunan itu. Portes dalam Tikson (2005:11) mengatakan bahwa pembangunan (development) merupakan transformasi ekonomi, sosial, dan budaya. Lebih lanjut Tikson (2005:11) mengatakan bahwa pembangunan merupakan proses perubahan yang direncanakan untuk memperbaiki berbagai aspek kehidupan masyarakat.

Berdasarkan pengertian di atas maka strategi pembangunan manusia dapat diartikan sebagai teknik atau cara dalam proses perubahan yang direncanakan untuk meningkatkan kemampuan manusia untuk berkinerja secara efisien dan efektif.

Evers (1987) mengemukakan tiga pola tentang birokratisasi. Pola pertama, birokratisasi sebagai proses rasionalisasi prosedur pemerintahan dan aparatur administrasi negara. Proses menjadi fokus dan dibahas secara luas dalam teori Weber yang oleh Evers dinamakan birokratisasi ala Weber atau Weberinisasi.

Pola kedua, proses birokratisasi dalam bentuk penambahan jumlah pegawai negeri dan pembesaran organisasi pemerintah. Dalam beberapa literatur ilmu sosial sering di sebut nama Parkinson, tokoh ilmu sosial dari Unversitas Singapura, yang menjadi terkenal karena "Parkinson's Law" yang telah diintroduksinya. Hukum Parkinson ini menyatakan bahwa 1) tiap pegawai negeri akan berusaha sekuat tenaga untuk meningkatkan jumlah pegawai bawahannya, dan 2) tiap pegawai akan selalu menciptakan tugas baru bagi dirinya sendiri, yang sering diragukan manfaat dan artinya. Karena itu laju birokratisasi akan senantiasa meningkat dan jumlah pegawai negeri pun akan naik secara otomatis, tidak tergantung dari tugas yang diperlukan. Pola semacam ini yang disebut Evers (1987) sebagai model birokratisasi Parkinson.

Pola ketiga, birokratisasi sebagai proses perluasan kekuasaan pemerintah dengan maksud mengontrol kegiatan ekonomi, politik, dan sosial dengan seperangkat peraturan, regulasi, kebijakan, dan bila perlu dengan pemaksaan. Proses ini disebut Evers (1987) sebagai model birokratisasi Orwell dan Orwellisasi sesuai dengan gambaran masyarakat yang digambarkan oleh George Orwell (1984).

Tesis utama dari teori birokrasi Weber (1978) adalah "birokrasi modern yang rasional diperlukan untuk ekonomi modern". Apa ciri-ciri birokrasi modern ini? Weber menggunakan konsepsi "Type Ideal" untuk menjawab pertanyaan ini. Menurut Weber suatu birokrasi modern mempunyai ciri-ciri 1) kegiatan birokrasi dilaksanakan secara teratur dengan batasbatas otoritas yang jelas, 2) ada hirarki kewenangan, 3) ada aturan yang jelas tentang perilaku, otoritas, dan tanggung jawab pegawai, dan 4) pegawai direkrut atas dasar merit system, bukan atas dasar ikatan kekerabatan.

Salah satu ciri penting birokrasi rasional Weber adalah sistem penggajian bagi pegawai sebagai alat untuk meningkatkan produktivitas birokrasi. Dalam hal ini birokrasi Indonesia 
mempunyai pola yang agak "unik", jika mengikuti pola pemikiran Weber, dan lebih mendekati pola imbalan dalam suatu birokrasi patrimonial yang lebih menyandarkan pada hubungan "patron" dan "client" atau yang secara populer dikenal sebagai "Bapakisme". Selama sistem penggajian seimbang dengan beban tugas, maka sistem itu dapat memacu produktivitas pegawai negeri. Hal ini sejalan dengan pikiran Osborne (2000) bahwa pegawai negeri dapat berkinerja bagus jika mereka punya uang yang cukup. Jika tidak, sistem seperti ini diragukan kemampuannya untuk menghasilkan birokrasi yang efektif dan efisien seperti yang dipikirkan Weber.

Cara lain yang ditempuh oleh pemerintah untuk meningkatkan prestasi pegawai negeri adalah dengan menaikkan gaji mereka. Gaji pegawai negeri golongan I, misalnya, hanya mencapai 30 persen dari kebutuhan fisik minimal keluarga dengan dua anak Effendi dkk. (1989) Tingkat gaji pegawai yang rendah ini pada akhirnya telah menciptakan birokrasi menjadi tidak produktif dan tingkat efisiensi menjadi rendah. Dengan kata lain, sistem remunerasi yang dipakai oleh Indonesia telah menyimpang dari prinsip-prinsip Weber. Dan karenanya sistem tersebut tidak akan menumbuhkan birokrasi yang rasional dan memiliki tingkat produktivitas dan efektivitas yang diperlukan untuk menopang pembangunan.

Peran birokrasi pemerintah dalam berbagai aspek kehidupan masyarakat di Indonesia, Thailand, dan Singapura cukup besar Ada sebagian penulis yang menganggap bahwa peran birokrasi dalam kehidupan ekonomi dan dunia usaha di Indonesia termasuk yang tertinggi di Asean (Effendi, 1995). Sistem birokrasi Indonesia ini oleh Jackson \& Pye (1978) dinamakan "masyarakat politikbirokratik", sedangkan Robinson \& Shaver (1986) menyebutnya sebagai "kapitalisme birokratik". Ini dimaksudkan untuk menggambarkan suatu sistem ekonomi dan politik sebagai tempat kegiatan ekonomi yang utama dimiliki oleh pemerintah dan sangat dikendalikan (well-controlled) melalui regulasi pemerintah. Sistem seperti ini menghambat proses pembangunan, terutama untuk jangka panjang.

Effendi (1993:419) memberikan konsep pembangunan kualitas manusia yang cukup sederhana, yakni suatu upaya yang terencana untuk meningkatkan kapasitas individu, masyarakat, dan suatu bangsa untuk dapat secara aktif menentukan masa depannya. Kapasitas tersebut mencakup kapasitas untuk produksi, kapasitas pemerintahan, kapasitas keberlanjutan (sustainable), dan kapasitas terhadap kesadaran saling interdependensi antarmanusia, antarmanusia dan lingkungannya, dan antarnegara. Bila didefinisikan seperti ini, pembangunan kualitas pada dasarnya adalah upaya untuk pengembangan inisiatif dan kreativitas sebagai sumberdaya pembangunan yang utama dalam rangka mencapai kesejahteraan material dan spiritual. Dalam konteks Indonesia, konsep pembangunan kualitas manusia ini perlu diperkaya dengan dimensi-dimensi yang khas, seperti prinsip-prinsip moral, agama, kesetiakawanan sosial dalam relasi antarmanusia, pengembangan rasionalitas, dan kemampuan menegakkan kemandirian (Salim, 1990:12).

Pergeseran titik berat pembangunan dari yang "lebih memperhatikan pertumbuhan ekonomi yang cepat" bergeser kearah yang "lebih menekankan kepada pemerataan" dan "pembangunan kualitas manusia dan kualitas masyarakat pada masa yang akan datang" (Effendi, 1993:419; Tjokrowinoto, 2004), membawa implikasi pada sistem administrasi yang digunakan untuk mencapai tujuan yang berbeda itu. Untuk melaksanakan pembangunan sumberdaya manusia diperlukan birokrasi yang tidak sama dengan yang dimiliki sekarang ini. Beberapa penulis, misalnya Brett (1988), meramalkan bahwa sistem administrasi Indonesia sekarang ini memiliki struktur 
organisasi, prosedur kerja, orientasi tugas, serta lingkungan birokasi yang lebih mendekati gambaran suatu "masyarakat politik-birokratik" ala Jackson \& Pye (1978) dan "kapitalisme birokratik" ala Robinson \& Shaver (1986).

Pembangunan kualitas manusia sebenarnya mencakup lima dimensi, yakni kapasitas untuk produksi, pemerataan, pemberian kewenangan yang lebih berat kepada rakyat, kesadaran yang lebih tinggi tentang interdependensi antarmanusia dan lingkungannya, maupun hubungan antardaerah dan antarbangsa, serta penekanan pada azas berkelanjutan (sustainability). Untuk perlu dikembangkan suatu sistem administrasi baru yang lebih cocok untuk pembangunan kualitas manusia, yakni sistem administrasi yang memiliki struktur lebih terbuka atau "organis-adaptif" Bennis (1969) dan Saxena (1985), prosedur yang lebih sederhana dan cepat, petugas yang berorientasi fasilitator, memiliki budaya pelayanan publik, serta lingkungan politikbirokratik yang mampu menciptakan "pengawasan" yang fungsional dan efektif terhadap birokrasi pemerintah.

\section{Pembangunan Kualitas Manusia Dalam Birokrasi}

Kiranya tidak berlebihan kalau dikatakan bahwa pemerintah, khususnya sistem administrasinya, pada akhirnya merupakan salah satu faktor penentu utama yang akan mempengaruhi keberhasilan pelaksanakan pembangunan kualitas manusia. Para kritikus birokrasi umumnya masih sepakat bahwa pertahanan birokrasi dalam pembangunan nasional tidak mungkin dapat digantikan sepenuhnya oleh lembaga swasta (Mathur, 1986:9). Namun di beberapa negara berkembang, termasuk Indonesia, sistem administrasi pembangunan menghadapi banyak hambatan yang sangat mempengaruhi kemampuan sistem tersebut dalam melaksanakan pembangunan kualitas manusia secara baik dan dengan amat memperhatikan martabat manusia.

Secara garis besar, hambatanhambatan pada birokrasi pembangunan dapat dikelompokkan menjadi dua, yakni hambatan proses orientasi Saxena (1986). Hambatan proses mencakup aspek struktur dan prosedur. Hingga kini struktur organisasi modern tetap dipandang sebagai model birokrasi yang tepat untuk melaksanakan pembangunan. Oleh para ahli sering kekurangberhasilan yang terjadi di banyak negara dihubungkan dengan birokrasi ini. Tetapi, yang menyebabkan model tersebut kurang berhasil bukanlah bentuknya itu, melainkan karena nilai-nilai dan struktur organisasi tradisional yang menyebabkan tumbuhnya distorsi bentuk organisasi modern menjadi sistem yang patrimonial. Pada sistem ini prinsip-prinsip nepotisme dan partikularistik berlaku. Kalau pada sistem ekonomi dikenal adanya dualisme antara ekonomi tradisonal-agraris dan ekonomi modern-industrial, maka dalam sistem administrasi dikenal adanya "sistem administrasi tradisional", yang menekankan pada ritualisme administratif yang inefisien, dan "sistem administrasi modern", yang menekankan pada rasionalisme administratif yang efisien Riggs (1957:5). Dualisme administrasi ini yang menyebabkan terhambatnya pertumbuhan budaya pelayanan publik, yang dalam birokrasi kita merupakan salah satu sebab kekurangmampuan administrasi pembangunan Indonesia.

Menurut Effendi (1993:421), Kartasapoetra (1994: 26), dan Abidin (2006), birokratisasi dan sentralisasi yang kuat dalam pengelolaan pembangunan telah menimbulkan struktur birokrasi yang amat hirarkis dan legalistis, sehingga prosedur lebih bertujuan untuk memenuhi tuntutan struktur daripada manfaat. Fleksibilitas dan arus komunikasi yang lancar amat diperlukan dalam penyelenggaraan program pembangunan. Dalam birokrasi pembangunan yang luar biasa besarnya di Indonesia, prosedur 
menjadi amat kaku dan lamban. Yang lebih memprihatinkan adalah prosedur yang mencekik ini ditumpangi oleh kepentingan pribadi serta dijadikan komoditi yang diperdagangkan untuk kepentingan pribadi maupun kelompok.

Peran birokrasi pemerintah yang kuat dan dominan dalam pengelolaan program pembangunan selama ini telah menimbulkan "mental penguasa atau mental priyayi" yang amat kuat dikalangan pejabat birokrasi, dan ini menjadi penghambat yang cukup besar dalam upaya menciptakan aparatur pemerintah yang terbuka, profesional, dan mampu menggalang partisipasi masyarakat dalam pembangunan. Dalam birokrasi seperti itu, prestasi seorang pejabat bawahan akan diukur dari kemampuannya mencapai target yang telah ditentukan atasan serta "kepuasan" atasan terhadap prestasi bawahan tadi. Karena itu sifat yang paling menonjol adalah semangat untuk menjaga "keseimbangan" dan "keselarasan" yang berimplikasi pada minimnya perhatian terhadap perubahan dan kemajuan --yang identik dengan pembangunan. Dengan kata lain, tumbuhlah dengan subur etos kerja status quo yang mendorong para pejabat lebih mempertahankan "keharmonisan" dalam segala hal.

\section{Strategi Meningkatkan Kualitas Manusia Birokrasi}

Kemampuan
pemerintah untuk melaksanakan
pembangunan manusia tidak mungkin
dapat ditingkatkan tanpa peningkatan
kualitas manusia dalam birokrasi
pemerintah itu sendiri. Kualitas yang
diperlukan oleh petugas birokrasi
pemerintah itu, antara lain, mencakup
ketaatan pada prinsip-prinsip moral dan
agama yang tinggi, rasa kesetiakawanan
sosial dalam hubungan sebagai pejabat dan
masyarakat, rasionalitas sebagai pejabat
yang merupakan individu organisasi atau
institusi yang lebih mementingkan tujuan

organisasi daripada tujuan individu, serta tingkat kemandirian yang juga tinggi.

Ada beberapa pilihan upaya yang dapat ditempuh oleh para perumus kebijakan, khususnya dalam bidang pembangunan administrasi. Semua upaya ini dilandasi oleh suatu asumsi bahwa dalam pelaksanaan pembangunan kualitas manusia, birokrasi modern adalah satusatunya wadah implementasi yang tersedia sampai saat ini. Dalam upaya untuk menghasilkan birokrasi yang memiliki efisiensi dan otonomi yang diperlukan untuk meningkatkan kualitas manusia, disadari bahwa hirarki yang terlalu subordinasi yang berlebihan. Karena itu, inti dari upaya untuk meningkatkan kualitas manusia dalam birokrasi meliputi upaya peningkatan produktivitas mereka melalui sistem insentif yang lebih baik, baik finansial maupun non-finansial, serta mengubah tata nilai serta tata lingkungan birokrasi melalui:

1. Pelatihan teknis dan moral. Program pelatihan yang tepat untuk menanamkan budaya produktivitas serta rasionalitas sebagai manusia birokrasi, haruslah mendapat penekanan dalam upaya reformasi administrasi di Indonesia. Program pelatihan manusia birokrasi yang baik dan tepat merupakan pilihan terbaik ketimbang upaya restrukturisasi birokrasi yang sering dilakukan selama ini.

2. Desentralisasi dan reintegrasi. Pembangunan kualitas manusia dan kualitas masyarakat amat memerlukan desentralisasi kewenangan kepada pemerintah daerah dan kepada masyarakat. Hanya pemerintah daerah yang tahu dengan lebih baik potensi yang dimilikinya serta bagaimana menggunakan potensi tersebut untuk mencapai tujuan yang mereka dambakan. Hambatan-hambatan antarsatuan kerja, di pusat dan daerah, perlu dikurangi secara sistematis dengan mengadakan reintegrasi kebijakan, program, dan kegiatan 
pembangunan oleh birokrasi pemerintah pusat dan daerah.

3. Birokratisasi. Tanpa pengawasan politik yang efektif, birokrasi pembangunan cenderung kurang berprestasi. Karena itu, sejalan dengan upaya menciptakan pengawasan demokratis yang efektif terhadap birokrasi, transformasi ini harus lebih luas dari transformasi yang dikenal selama ini, yang bertujuan untuk memperbaiki akuntabilitas dan partisipasi. Yang diperlukan adalah pemberian kekuasaan kepada masyarakat untuk mengembangkan batas-batas organisasi sosial yang bebas dalam suatu masyarakat (civil society).

Menurut World Bank, konsep pembangunan SDM, dalam konteks makro, diartikan sebagai keseluruhan proses aktivitas perluasan spektrum pilihan untuk meningkatkan kemampuan manusia, yang didalamnya tercakup berbagai aktivitas, yaitu pengembangan pendidikan dan pelatihan, kesehatan dan gizi, kesempatan kerja, lingkungan hidup yang sehat, pengembangan di tempat kerja, dan kehidupan politik yang bebas (UNDP, 2001).

Berdasarkan laporan UNDP (2001) diketahui bahwa tingkat pendidikan dan pelatihan diberbagai negara berkorelasi secara positif dengan berbagai indikator lain, seperti penggunaan teknologi informasi dan komunikasi (penggunaan telepon atau internet), persentase wanita di bidang legislatif, dan alokasi anggaran yang responsif pada sektor pendidikan.

Dari beberapa definisi yang telah dikemukakan di atas dapat ditarik kesimpulan bahwa pengembangan manusia birokrasi dilakukan melalui dua cara, yakni pendidikan dan pelatihan. Pendidikan berorientasi kepada peningkatan pemahaman teori, sedangkan pelatihan lebih ditujukan kepada praktik atau teknis. Jadi strategi pengembangannya adalah dengan memberikan birokrasi kerangka kerja dalam meningkatkan kemampuan dan berkembang untuk mengantisipasi dan mendeteksi perubahan lingkungan melalui pendidikan dan pelatihan.

\section{Strategi Pembangunan Sumber Daya Birokrasi}

Pada dasarnya profesionalisme birokrasi yang dituntut oleh good governance tidak terbentuk dengan sendirinya. Oleh karena itu Tjokrowinoto (2004:11) mengatakan bahwa perlu dilakukan beberapa strategi, yaitu (1) Role Modeling. Standar perilaku dan pola perilaku birokrat terbentuk, antara lain, melalui keteladanan. Oleh karena itu spartan elite akan amat menentukan sosok profesionalisme birokrasi; (2) Rekrutmen. Kondisi kerja dan pelatihan. Proses rekrutmen yang objektif, kondisi kerja yang kondusif, dan pelatihan yang menggunakan pendekatan metodik dan dedaktik yang tepat merupakan wacana pembentukan profesionalisme yang efektif; (3) Pendekatan Proses Belajar. Learning process approach sebagaimana yang dikemukakan oleh Korten (2001). Pendekatan ini memberi marjin toleransi yang besar bagi birokrasi untuk berbuat kesalahan (embaring error) dalam proses pembentukan dan penyempurnaan profesionalisme karena kesalahan akan menjadi input untuk perbaikan diri. Melalui kesalahan tadi, manusia birokrasi akan belajar efektif (learning to effective), kemudian akan melangkah menuju belajar efisien (learning to be efficient), dan pada akhirnya akan belajar berkembang (learning to be expand); (4) Dilakukan secara bersama-sama dengan penguatan birokrasi (organizational strengthening) yang memfokuskan diri pada sistem manajemen untuk meningkatkan kinerja pada struktur mikro dan reformasi kelembagaan (institutional reform) yang memfokuskan diri pada struktur makro kelembagaan; (5) Memerlukan kontrol sosial dari masyarakat sipil. Meski nampaknya merupakan kontradiksi, di satu sisi profesionalisme birokrasi menuntut 
kemampuan empowering masyarakat sipil, melalui pembentukan enabling social setting, namun di sisi lain masyarakat sipil perlu melakukan social control terhadap birokrasi. Hal ini menuntut adanya mutual learning process antara birokrasi dan masyarakat.

Lebih lanjut Tjokrowinoto (2004:9) mengemukakan bahwa salah satu kualitas manusia birokrasi yang dituntut oleh good governance adalah kualitas entrepreneurial yang dapat menjembatani antara state dan market. Karena dalam konteks kecenderungan liberalisasi ekonomi saat ini, kualitas entrepreneurial diperlukan untuk mengintervensi pasar secara selektif berdasar atas pertimbangan yang bersifat ad hoc untuk menjamin berfungsinya pasar secara sehat dan menghindari "the blind force of the market" (Thoha, 2005:163).

\section{Kompetensi Birokrat yang Diharapkan}

$\begin{array}{ccc}\begin{array}{c}\text { Adapun } \\ \text { dibutuhkan } \\ \text { birokrat, }\end{array} & \begin{array}{c}\text { yang } \\ \text { menurut }\end{array}\end{array}$ Tjokrowinoto (2004:9), yang berkaitan dengan hal tersebut adalah (1) Sensitif dan responsif terhadap peluang dan tantangan baru yang timbul di dalam pasar. (2) Tidak terpaku pada kegiatan-kegiatan rutin yang terkait dengan fungsi instrumental birokrasi, akan tetapi harus mampu melakukan terobosan (break through) melalui pemikiran yang kreatif dan inovatif. (3) Mempunyai wawasan futuristik dan sistemik. (4) Mempunyai kemampuan untuk mengantisipasi, memperhitungkan, dan meminimalkan risiko. (5) Jeli terhadap potensi sumbersumber dan peluang baru. (6) Mempunyai kemampuan untuk mengkombinasikan sumberdaya menjadi resource mix yang mempunyai produktivitas tinggi. (7) Mempunyai kemampuan untuk mengoptimalkan sumberdaya yang tersedia dengan mengeser sumber kegiatan yang produktivitasnya rendah menuju kegiatan yang mempunyai produktivitas tinggi.
Birokrat yang mempunyai kualitas entrepreneurial seringkali secara sengaja melakukan destabilizing force dalam rangka menimbulkan creative destruction equilibrium yang satu menunju equilibrium yang lain yang lebih tinggi. Menurut Tjokrowinoto (2004:10), sikap rasionalitas, imparsialitas, dan impersonal, mendasari kemampuan profesional birokrat. Kompetensi birokrasi lain yang dituntut oleh good governance adalah kemampuan untuk menjembatani antara the state dan civil society. Hal ini tersirat, baik dalam definisi Adil Khan dalam Tjokrowinoto. (2004:10) yang menegaskan bahwa good governance merupakan cara mengatur pemerintahan yang memungkinkan layanan publiknya efisien, sistem pengendaliannya bisa diandalkan, dan administrasinya bertanggung jawab kepada publik.

Selanjutnya menurut J.B. Say yang dikutip oleh Osborne \& Peter (2000) semangat entrepreneurship tidak hanya milik korporasi swasta saja, melainkan dapat pula dimiliki oleh administrasi publik, organisasi non profit, maupun administrasi sektor lainnya.

\section{KESIMPULAN}

Pada dasarnya sumberdaya yang paling bernilai dalam suatu birokrasi adalah sumberdaya aparaturnya. Aparatur melaksanakan dan mengkoordinasi tugastugas, memproses input menjadi output. Birokrasi akan runtuh tanpa manusia birokrasi didalamnya. Jadi wajar kalau manusia birokrasi (birokrat) menjadi perhatian yang serius untuk menciptakan efisiensi dan efektivitas di dalam birokrasi. Untuk menciptakan birokrasi yang efisien dan efektif, perlu pembangunan kualitas manusia birokrasi itu sendiri. Pembangunan sumberdaya manusia bertujuan untuk menjembatani berbagai gap antarvariabel sumberdaya manusia sedemikian rupa sehingga terdapat match and link sepenuhnya antarvariabel tersebut. Pembangunan sumberdaya manusia pada 
hakikatnya adalah pembangunan manusia sebagai suatu genus makhluk menjadi sumberdaya manusia.

\section{DAFTAR PUSTAKA}

Abdullah, S. (1985). Birokrasi dan Pembangunan Nasional: Studi tentang Peranan Birokrasi Lokal dalam Implementasi Programprogram Pembangunan di Sulawesi Selatan. Ujung Pandang: Universitas Hasanuddin.

Abidin, S.Z. (2006). Dinamika Reformasi Administrasi Publik di Indonesia. Jakarta: Suara Bebas.

Bennis, W G. (1969). Changing Organizations dalam W.G. Bennis, K.B. Benne dan R. Chin, Eds. The Planning of Change. New York: Holt Rinehart and Winston.

Bryant \& White (1987). Manajemen Pembangunan umtuk NegaraNegara Berkembang. Jakarta: LP3ES.

Brett. E.A. (1988). Adjustment and the State: the Problems of Administrative Reform. IDS Bulletin. IV:4.

Dwiyanto, A dkk. (2006). Reformasi Birokrasi Publik di Indonesia. Yogyakarta: Gadjah Mada University Press.

Effendi, Sofyan. (1989). Pelayanan Publik, Pemerataan, dan Administrasi Negara Baru. Prisma.

Effendi, Sofyan. (1990). Pembangunan Kualitas Manusia: Suatu Perspektif Administrasi Negara. Yogyakarta: Gadjah Mada University Press.

Evers, Hans-Dieter. (1988). The Bureaucratization of Southeast Asia, Comparative Studies in Society and History, 29 (4) 666-685.

Jackson, Karl D. \& Pye, Lucian. (1978). Political Power and Communication in Indonesia. Berkeley: University of California Press.

Kartasapoetra, G. (1994). Debirokratisasi dan Deregulasi. Jakarta: Rineka Cipta.
Korten, David C., (2001). Menuju Abad ke-21: Tindakan Sukarela dan Agenda Global. Jakarta (Terjemahan) Yayasan Obor Indonesia.

Osborne, David \& Plastrik, Peter. (2000). Memangkas Birokrasi: Lima Strategi Menuju Pemerintahan Wirausaha. Jakarta: PPM.

Riggs, Fred W. (ed.). (1976). Fronties of Development Administration. Durham, North Carolina: Duke University.

Robinson, John P. \& Shaver, P.R.. (eds.). 1986. Measure of Social Psychological Attitudes. Ann Arbor: Mitch Institute for Social.

Salim, Emil. 1990, Konsep Pembangunan Berkelanjutan, Jakarta.

Saxena, A.P. 1985. Peningkatan Produktivitas Tatalaksana Pemerintahan. Prisma,

Tikson, Deddy T. (2005). Teori Pembangunan di Indonesia, Malaysia dan Thailand. Makassar: Ininnawa.

Thoha, M. (2005). Birokrasi dan Politik di Indonesia. Jakarta: Raja Grafindo Persada.

Tjokrowinoto, Moeljarto. (2004). Birokrasi dalam Polemik. Pustaka Pelajar bekerjasama dengan UMM Malang.

UNDP. (2001). Human Development Report. New York: Oxford University Press.

Weber, Max. (1978). Economy and Society. New York: University California Press.

Wibawa, Samodra. (2005). Peluang Penerapan New Public Manajemen di Indonesia. Yogyakarta: Gadjah Mada University Press.

Wrihatnoto, Randy R. \& Nugroho, Riant D. (2006). Manajemen Pembangunan Indonesia: Sebuah Pengantar dan Panduan. Jakarta: Gramedia. 